\title{
Human red blood cells-2
}

\section{Omar S. Hajjawi}

Department of Biology, Arab American University, P.O.Box 240, Jenin, Israeli Occupied Territories of Palestine.

\section{Email address:}

ohajjawi@aauj.edu

\section{To cite this article:}

Omar S. Hajjawi. Human Red Blood Cells-2. American Journal of Life Sciences. Vol. 1, No. 5, 2013, pp. 215-227.

doi: 10.11648/j.ajls.20130105.13

\begin{abstract}
Biochemists and cell biologists, who are interested in membranes, tend to regard the human red blood cell ambivalently. On one hand, red blood cells lack nuclei and the various intracellular organelles, yet that are highly specialized for a particular respiratory function. On the other hand, the human red blood cell presents an excellent model for membrane transport function.
\end{abstract}

Keywords: Human Erythrocyte, Electrochemical Potential, Donnan Equilibrium, Haemoglobin, Red Blood Cell Shape, Permean Ions, Osmotic Pressure, Band 3, Facilitated Transport, $\mathrm{K}^{+} / \mathrm{Cl}^{-}$Cotransport, $\mathrm{K}^{+}\left(\mathrm{Na}^{+}\right) / \mathrm{H}^{+}$Exchanger, $\mathrm{Na}^{+} / \mathrm{K}^{+}$-Atpase, Anion Transport.

\section{Transport Systems in the Human Red Blood Cell}

Why are membranes so important to cells? The most obvious answer is that membranes enclose and define the limits of living cells. We should also note that a membrane represents a natural kind of aggregation of amphipathic molecules, i.e. molecules containing both hydrophobic and hydrophilic ends. The packing of such molecules in a bilayer also represents a natural arrangement for a boundary between two different aqueous phases (Fig. 13). In addition, membranes are the natural "habitat" for many relatively nonpolar molecules formed by metabolism. Included are many proteins with hydrophobic surfaces. Thus, it is not too speculative to believe that proteins could exist which could traverse the membrane, presenting hydrophilic patch to one side or the other.

Water is present in native membranes, and proton magnetic resonance studies $[162,164]$ indicate that much of it is associated with protein. Most of the water is loosely bound, the molecules being considerably less mobile than liquid water, and a little is tightly bound comparable with water in a solid hydrate.

After: Singer, S.J. and Nicolson, G. L. (1972)"The fluid mosaic model of the structure of cell membranes", Science, vol. 175, pp. 723; Wessells, N.K. and Hopson, J.L. (1988) Biology, p.108.New York: Random House, Inc.

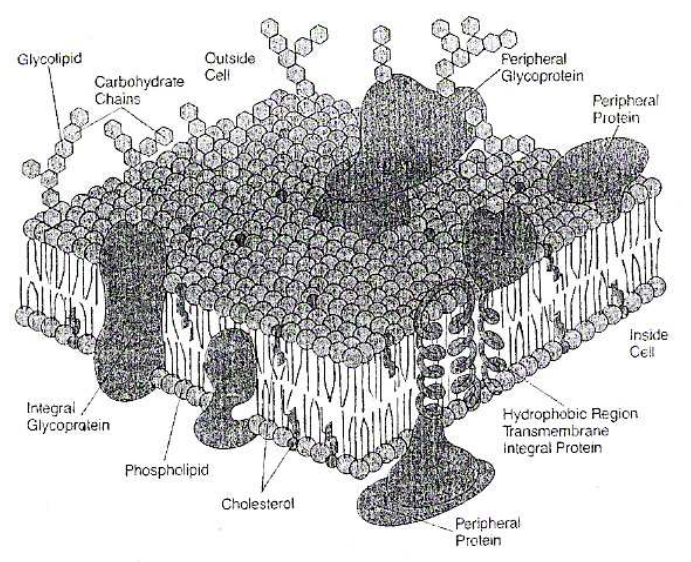

Fig. 13. The fluid-mosaic model of membrane structure updated.

The human red blood cell membrane which possesses both $\mathrm{Na}^{+} / \mathrm{K}^{+}$activated $\mathrm{Mg}^{2+}$ dependent-ATPase and $\mathrm{Ca}^{2+}$ ATPase, supports cation concentration gradients. As a result, freely permeable anionic species also form concentration gradients (Table 5) which are further influenced by impermeable anionic cytoplasmic proteins [164]. The human red blood cell possesses a membrane potential $\left(\mathrm{E}_{\mathrm{m}}\right)$ which is typically $-10 \mathrm{mv}$ [165].

After: Tyuma, I and Shimizu, K. (1970)"Effect of organic phosphates on the difference in oxygen affinity between fetal and

Adult human hemoglobin", Fed.Proc., vol.29, pp.11121114; Lepke, S. and Passow, H. (1976)"The effect of pH at hemolysis on the reconstitution of low cation permeability 
in human erythrocyte ghosts ", Biochim. Biophys. Acta., vol.455, pp.353 -370; Geers, C. and Gros, G. (2000)"Carbon dioxide transport and carbonic anhydrase in blood and muscle", Physiol Review, vol. 80 (2), pp.681-715.

Table 5. Distribution of inorganic ions in the arterial human red blood cell.

\begin{tabular}{|c|c|c|c|c|c|c|}
\hline & $\mathbf{H}^{+}$ & $\mathbf{O H}^{-}$ & $\mathrm{HCO}_{3}^{-}$ & $\mathrm{Cl}^{-}$ & $\mathrm{Na}^{+}$ & $\mathbf{K}^{+}$ \\
\hline $\begin{array}{l}\text { Intracellular } \\
\text { medium }\end{array}$ & $6.25 \times 10^{-}$ & $1.6 \times 10^{-7}$ & 16 & 77 & 16 & 134 \\
\hline $\begin{array}{l}\text { Extracellular } \\
\text { medium }\end{array}$ & $\begin{array}{l}3.99 \times 10^{-} \\
-\end{array}$ & $2.5 \times 10^{-7}$ & 25 & 115 & 140 & 4 \\
\hline$[\text { Ion }]_{\text {in }} /[\text { Ion }]_{\text {out }}$ & 1.56 & 0.64 & 0.64 & 0.67 & 0.11 & 33.5 \\
\hline
\end{tabular}

(Concentrations are given in $\mathrm{mM}$ )

The red blood cell membrane is rather impermeable towards hydrophilic molecules owing to its hydrophobic nature. However, selective exchange of substances between the intracellular and extracellular compartments is achieved via three main permeation modes: simple diffusion, facilitated diffusion and active transport (Table 6 and Fig.14).

Adapted from: Crane, R.K. (1977)"The gradient hypothesis and other models of carrier-mediated active transport", Rev.Physiol. Biochem.Pharmacol., vol.78, pp.99-159; Deuticke, B. (1977)" Properties and structural basis of simple dif- fusion pathways in the erythrocyte membrane", Rev.Physiol. Biochem. Pharmacol., vol.78, pp. 1-98; Lieb, W.R. (1982)"A Kinetic Approach to Transport Studies", in Red Cell Membranes a Methodological Approach, Ellory, J.C. and Young, J.D. (eds).London: Academic Press Inc (London) Ltd; Horton, H.R., Moran, L.A., Scrimgeour, K.G., Perry, M.D. and Rawn, J.D. (2006) Principles of Biochemistry, $4^{\text {th }}$ edn.,p.278.Upper Saddle River, NJ: Pearson Education, Inc.

Table 6. Properties of major transport systems in the human red blood cell.

\begin{tabular}{|c|c|c|c|c|}
\hline & Property & Simple diffusion & Facilitated transport & $\begin{array}{l}\text { Active transport } \\
\text { (primary \& secondary) }\end{array}$ \\
\hline $\mathrm{i}$ & "Transporter" & Lipid & Protein & Protein \\
\hline ii & Net flux & $\begin{array}{l}\text { Ceases at electro- } \\
\text { chemical equilibrium }\end{array}$ & $\begin{array}{l}\text { Ceases at electro- } \\
\text { chemical equilibrium }\end{array}$ & $\begin{array}{l}\text { Possible to move a solute up electro- } \\
\text { Chemical gradient }\end{array}$ \\
\hline iii & Energy coupling & No & $\begin{array}{l}\text { Indirectly } \\
\text { (via membrane bound ATPase) }\end{array}$ & $\begin{array}{l}\text { Directly } \\
\text { (via membrane bound ATPase) }\end{array}$ \\
\hline iv & Specificity & Low & $\begin{array}{l}\text { High } \\
\text { (capable of distinguishing between } \\
\text { enantiomers) }\end{array}$ & $\begin{array}{l}\text { High } \\
\text { (capable of distinguishing between } \\
\text { enantiomers) }\end{array}$ \\
\hline $\mathrm{v}$ & Saturation & None & Exhibit saturation & Exhibit saturation \\
\hline vi & Counter transport & No & Yes & $\begin{array}{l}\text { Irreversible under physiological } \\
\text { conditions }\end{array}$ \\
\hline
\end{tabular}

Adapted from: Wessells, N.K. and Hopson, J.L. (1988) Biology, p.111. New York: Random House, Inc.; Seifter, J., Ratner, A. and Sloane, D. (2005) Concepts in Medical Physiology, p.16. Baltimore, MD: Lippincott Williams \&
Wilkins; Nelson, D. L. and Cox, M.M. (2008) Lehninger Principles of Biochemistry, $5^{\text {th }}$ edn., p.389. New York: W.H.Freeman and Company.

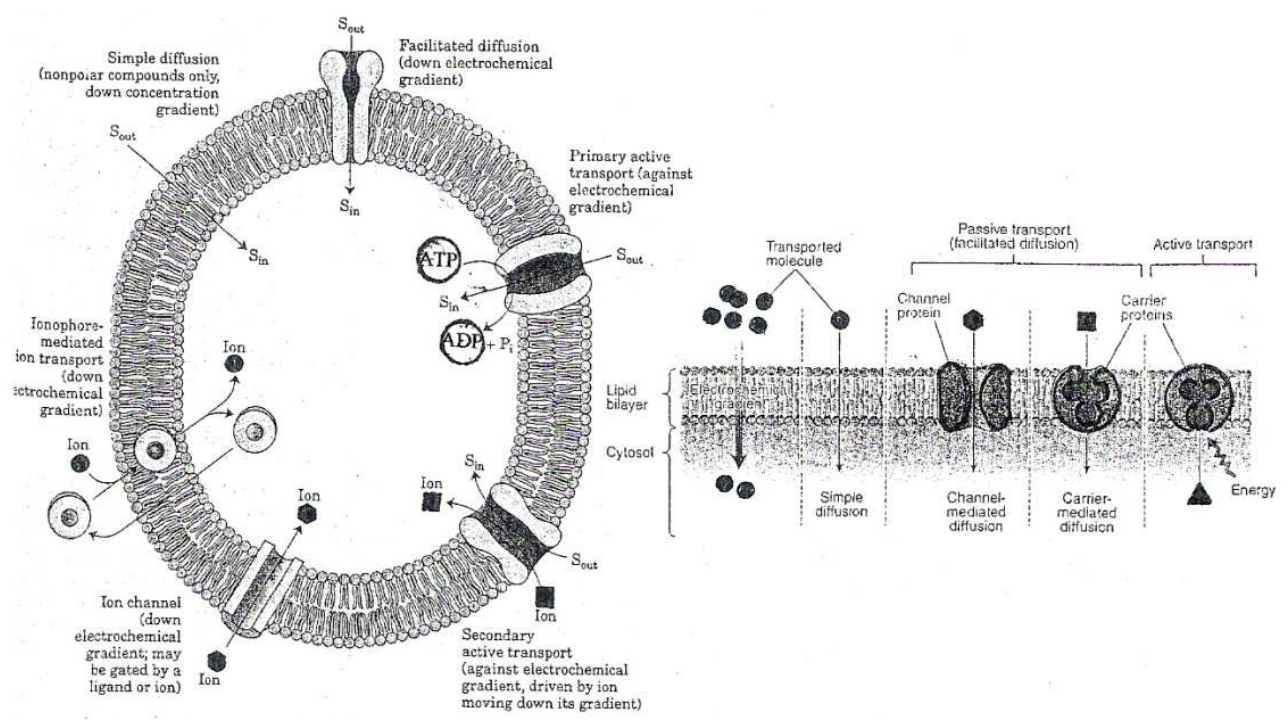

Fig. 14. Types of transport. 
Transport kinetics is the movement of molecules across cell membranes in action from one aqueous environment to another. It is therefore restricted to movement of solute molecules and of water. Gases, such as oxygen and carbon dioxide, which are important in cellular metabolism, pass in and out of the cell in a dissolved state and the limiting factor in the rate of transfer is the extent to which the gases are soluble in the aqueous environment. Carbon dioxide is very soluble in water and passes freely through membranes but oxygen has a much more limited solubility and this becomes a limiting factor in cellular metabolism.

\subsection{Simple Diffusion}

Random Brownian (thermal) movement of molecules in solution cause a solute to disperse from areas of high concentration until the solution is homogeneous [166]. This process of passive diffusion can also occur across the red blood cell membrane (Fig.15), although the apolar core of the bilayer hydrocarbon chains adds a serious constraint on the type of molecule that can diffuse into the cell $[133,167,168]$. Charged molecules and large molecules are almost entirely excluded from this permeation mechanism and even small molecules such as water diffuse at $10^{-2}-10^{-3}$ times the rate of that observed across an aqueous barrier [43].

The two sides of the trough contain solutions with high

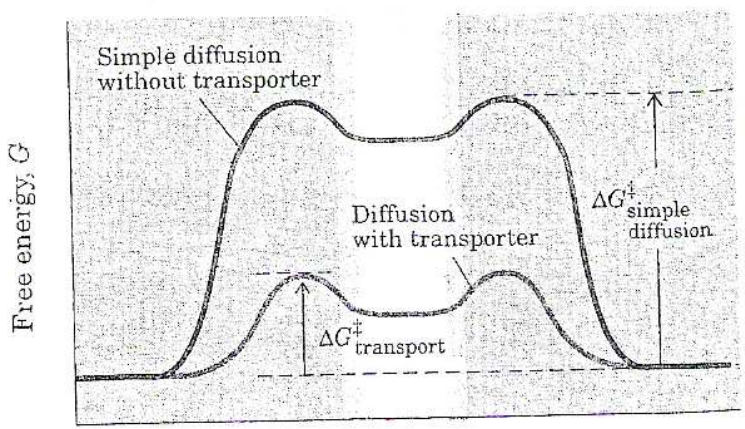

Fig.15. A simple diffusion system and energy changes.

The force responsible for simple diffusion is strictly speaking not a concentration gradient ( c), but a gradient of chemical potential $(\mu)$. These two quantities are related (Eq.13) [169].

$$
c=e^{\mu / R T}
$$

where $\mathrm{R}$ is gas constant and $\mathrm{T}$ the absolute temperature.

Empirically, this diffusion is described by Fick's first law of diffusion [171,172],

$$
J=\left(\frac{d n}{d t}\right)=-D A\left(\frac{d c}{d x}\right)=-D A \frac{d e^{\mu} / R T}{d x}
$$

where $\mathrm{J}$ is the diffusion flux, $\mathrm{dn} / \mathrm{dt}$ is the number of and low salt concentrations, separated by a porous membrane. Free water molecules and sodium and chloride ions move randomly. The more concentrated ions on the right side strike the permeable membrane pores in more frequently than do the less concentrated ions on the left side. As a result, more sodium and chloride ions move from right to lift than the reverse until equilibrium is reached. Water behaves the same way, i.e. high concentration of water molecules move from left to right according to concentration gradient (the more diluted sodium chloride solution on the left, the higher concentration of water molecules and where water's free energy is higher too). So net movement of water and of $\mathrm{Na}^{+}$and $\mathrm{Cl}^{-}$ions occur in the opposite directions until concentrations on both side are in equilibrium state. In simple diffusion, removal of the hydration shell is highly endergonic and the energy of activation $\left(\Delta G^{\#}\right)$ for diffusion of the solute, whereas a transporter protein reduces the level of $\Delta G^{\#}$ by forming noncovalent interactions with the dehydrated salt and by providing a hydrophilic transmembrane passage.

Adapted from: Donnan, F.G.(1924)"The theory of membrane equilibria", Chem Rev.,vol. 1, pp.73-90; Wessells, N.K. and Hopson, J.L. (1988) Biology, p.110. New York: Random House, Inc.; Nelson, D. L. and Cox, M.M. (2008) Lehninger Principles of Biochemistry, $5^{\text {th }}$ edn., p.390. New York: W.H.Freeman and Company.

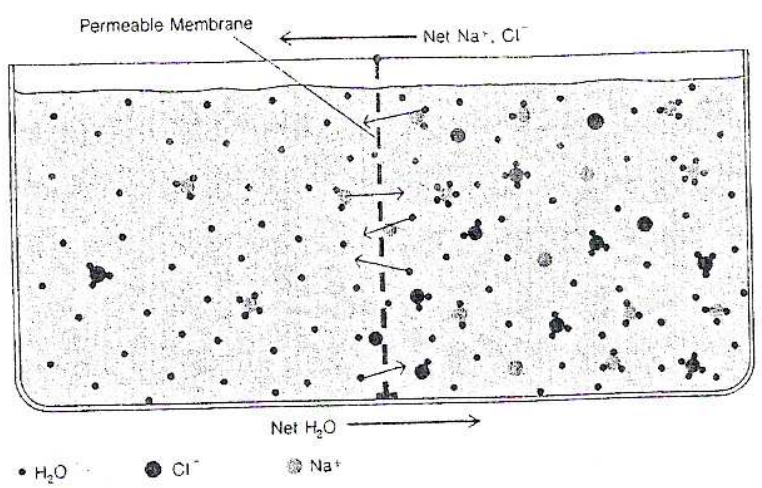

molecules per unit time passing through the membrane of surface area A and thickness $\mathrm{x}$, under I finite concentration gradient c. D is the diffusion coefficient or diffusivity which is a small number in usual units $\left(\mathrm{cm}^{2} \cdot \mathrm{s}^{-1}\right)$ and in aqueous solution it does not change rapidly with molecular weight, $\mathrm{M}_{\mathrm{wt}}$. The negative sign signifies that solute moves in direction of decreasing concentration. However, as these differential rates depend partly on the nature of the membrane, D must also contain membrane specific factors [172]. D can also be expressed as $\omega \mathrm{RT}$ where $\omega$ is the mobility; $\mathrm{R}$ is the gas constant, and $\mathrm{T}$ the absolute temperature.

By analogy with Ohm's Law, $\mathrm{R}=\mathrm{V} / \mathrm{I}$ (Resistance $=$ Voltage divided by Current), the diffusion coefficient $\mathrm{D}$ can be considered as a conductance which is equivalent to the 
reciprocal of resistance, $\mathrm{R}_{\mathrm{m}}$, or frictional coefficient between the diffusate and membrane [173]. Therefore, the computed value of the erythrocyte membrane resistance, which is $\sim 10^{5}-10^{6} \mathrm{ohm} . \mathrm{cm}^{2}[36,174]$ can be employed for further insight into the nature of ion conductivity.

The classical interpretation of diffusion in terms of molecules changing place within one another in solutions as a result of random thermal motion is that of Einstein $[171,175]$. He derived two important equations which are still used in the interpretation of diffusion measurements. The first equation (Eq. 15), Stokes-Einstein equation, shows that the diffusion coefficient for a specified molecular species varies in different solvents and is inversely proportional to the frictional,

$$
\mathrm{D}=\left(\frac{\mathrm{RT}}{\mathrm{L}}\right)\left(\frac{1}{f}\right)=\frac{\mathrm{KT}}{6 \pi \mathrm{r} \eta}
$$

coefficient $f$ between solute and solvent, RT the kinetic energy expression, $L$ the Avogadro number $\left(6.022 \times 10^{23}\right.$ $\left.\mathrm{mol}^{-1}\right)$, K Boltzmann's constant (1.381 x $\left.10^{-23} \mathrm{JK}^{-1}\right), \mathrm{T}$ absolute temperature $\left({ }^{\circ} \mathrm{K}\right), \mathrm{r}$ molecular radius and $\eta$ viscosity of solution. Assuming spherical solute molecules of radius $r$ in a medium of viscosity $\eta$, in which the solute obeys Stokes' Law, $f=6 \pi \eta r$ [176].The diffusion coefficient and molecular size can be related theoretically, and in practice the assumptions are imperfectly valid.

We can see from Eq. 15 that, as a transport mechanism, diffusion in free solution is not very selective with respect to molecular size; the values of $\mathrm{D}$ are roughly proportional to $\mathrm{M}_{\mathrm{wt}}{ }^{-1 / 2}$ for small molecules and $\mathrm{M}_{\mathrm{wt}}{ }^{-1 / 3}$ for larger ones [177]. Perhaps more important from the point of view of membrane transport is the comparison between diffusion in water and oil; taking vegetable oils as roughly analogous media to biological membranes. D for the same substance in oil would be $10^{-2}$ fold that in water, or less [178].

Einstein's important equation (Eq.16) in biology is used to calculate $\Delta$, the distance moved by a molecule in a very short,

$$
\Delta^{2}=2 \mathrm{D} \tau
$$

time $\tau$ during which $\mathrm{dc} / \mathrm{dx}$ is assumed to be effectively unaltered $[171,175]$. In this form, the equation applies to a situation in which the concentration gradient is unidirectional. For diffusion in three dimensions Eq.17 replaces Eq. 16 .

$$
\Delta^{2}=6 \mathrm{D} \tau
$$

Movement of ionized solutes are influenced also by potential (electrical) gradients, but the rate of flow of the solute may still be described in simple terms by the Nernst Planck equation [179],

$$
J=-\omega C\left(\frac{R T}{C} \cdot \frac{d C}{d X}+z F \frac{d \psi}{d X}\right)
$$

where $\mathrm{z}$ is number of electrical charges on permeating molecules, $F$ is the Faraday $(96,500$ coulomb/mol), d $/ \mathrm{dx}$ is electrical potential gradient across membrane and the expression in brackets is the combined force due to concentration and electrical gradients, that is, the electrochemical gradient. The characteristics of solute movement through membranes by simple passive permeation can be described completely by these equations.

Studies of the rates of passive movements of a variety of solutes across cell surface membranes have provided significant information on the chemical and physical nature of these barriers [180]. Quantitative analysis of permeability phenomena is complicated by the simultaneous movement of solute and solvent molecules, but methods have been devised which circumvent this and facilitate quantitative comparisons of permeability characteristics of various natural and artificial membranes [35]. For instance, methods have been developed for following volume change in erythrocytes which result from the creation of a transmembrane concentration gradient with respect to a penetrating non-electrolyte solute. The graph of volume change against time can be extrapolated to zero time to obtain an initial rate of transfer [181]. Further extrapolations from experiments with a variety of solutes, e.g. glycerol, sucrose, urea, formamide, and a variety of concentration gradients provided kinetic parameters which have been expressed in terms of hypothetical pores radii

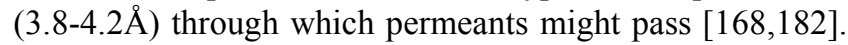
The calculations involve a number of assumptions concerning the applicability of particular physical laws to movement of solutes through membranes, but the values obtained for pore radii have provided a useful basis for comparing the permeability characteristics of red blood cell membranes to water and other small uncharged molecules [163].

\subsection{Facilitated Transport}

Many substances glucose [183,184], amino acids $[185,186]$, and anions $[46,187,188,189]$ can penetrate the erythrocyte membrane more rapidly than would be predicted from their chemical and physical properties on the basis of their diffusion coefficients (Eq. 14). Therefore, there is evidence of an extra mechanism, the kinetics of which is readily distinguishable from the passive permeation; it shows a much lower activation energy (Fig. 16) and somewhat less marked both temperature and $\mathrm{pH}$ dependence, and no metabolic energy is required to drive the process although it could be argued that energy is expended in maintaining an intact membrane. The net transport of molecules is therefore always in a direction of decreasing electrochemical potential. This gradient provides the driving force for facilitated diffusion irrespective of whether this is a gradient of the solute transported or another molecular species to which movement of the first is coupled $[38,190]$. 


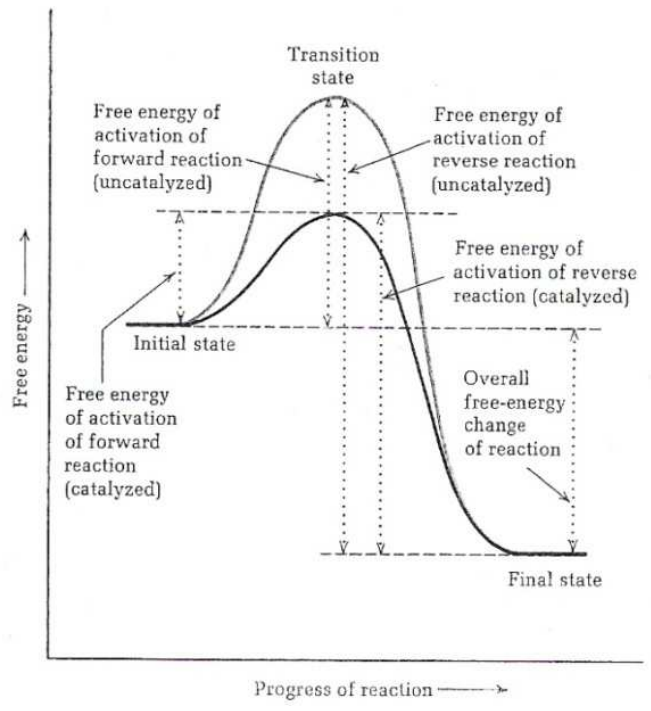

Fig. 16. Energy profile for a chemical reaction, uncatalyzed and catalyzed.

The mechanism is identified as a mediated permeation in which some specific membrane bound proteins play a role. Passive and mediated permeations are more generally distinguishable on the basis of differences in the kinetics and specificities of the two processes. A system which mediates solute movement is invariably of limited capacity and should eventually become saturated. The simple diffusion coefficient and the Nernst-Planck equations (Eq. 15, Eq. 18) of passive permeation are not appropriate for describing the kinetics of mediated transport. The most useful attempts to study the transporters of such systems in action have assumed a characteristic affinity $\left(\mathrm{K}_{\mathrm{m}}\right)$ of the solute molecule with some protein component of the membrane. So, the translocation of solutes via such processes is analogous to enzyme-substrate intermediate complexation, in which such a formation of ternary complex in the membrane decreases the activation energy of solute transport [133,191].

A chemical reaction such as $\left[\mathrm{A}_{\text {extracellurar }}\right] \rightarrow\left[\mathrm{P}_{\text {intracellular }}\right]$ takes place because of electrochemical potential gradient. Note the difference between the magnitude of activation energy $\left(\Delta \mathrm{G}^{\mathrm{o \ddagger}}\right)$ and the standard free energy change of the reaction $\left(\Delta \mathrm{G}^{\circ}\right)$. When a given population of [A] molecules possess enough energy to attain activated condition, i.e. transition state, in which the probability is very high that a chemical bond will be made or broken to form product [P]. This transition state is at the top of the energy barrier separating the reactants, $\left.A_{\text {extracellurar }}\right]$, and the resultants, $\left[\mathrm{P}_{\text {intracellular }}\right]$. The rate of the reaction (or transport) is proportional to the concentration of this transition-state species. The rate of chemical reaction can be accelerated by addition of a catalyst. Catalysts combine transiently with the reactants to produce a transition state having a lower energy of activation than the transition state of the uncatalyzed reaction. When the reaction resultants are formed, the free catalyst is regenerated.

Adapted from: Nelson, D. L. and Cox, M.M. (2008) Lehninger Principles of Biochemistry, $5^{\text {th }}$ edn. p.25. New York: W.H.Freeman and Company.

A number of enzyme poisons are known to markedly and specifically inhibit facilitated transport when added in concentrations low enough to exclude any non specific inhibition on membrane permeability [192]. Also, the transport sites possess stereo chemical specificity to discriminate between D- and L-stereoisomers of certain solutes [181,193,194]. Such characteristics have been confirmed for reconstituted preparations in phospholipids vesicles [195,196]. Certain kinetic features have been attributed to facilitated transport, for instance 'uphill' movement of solutes $[36,136]$ and self-inhibition $[88,117]$ Since there is similarity between the kinetics of facilitated transport systems and enzyme reactions, the flux $J_{1 \rightarrow 2}$ of a permeant in one direction is described by adopting a Michaelis-Menten [197] type expression,

$$
\mathrm{J}_{1} \rightarrow_{2}=\frac{\mathrm{J}_{\max } \mathrm{C}_{1}}{\mathrm{~K}_{\mathrm{m}}+\mathrm{C}_{1}}
$$

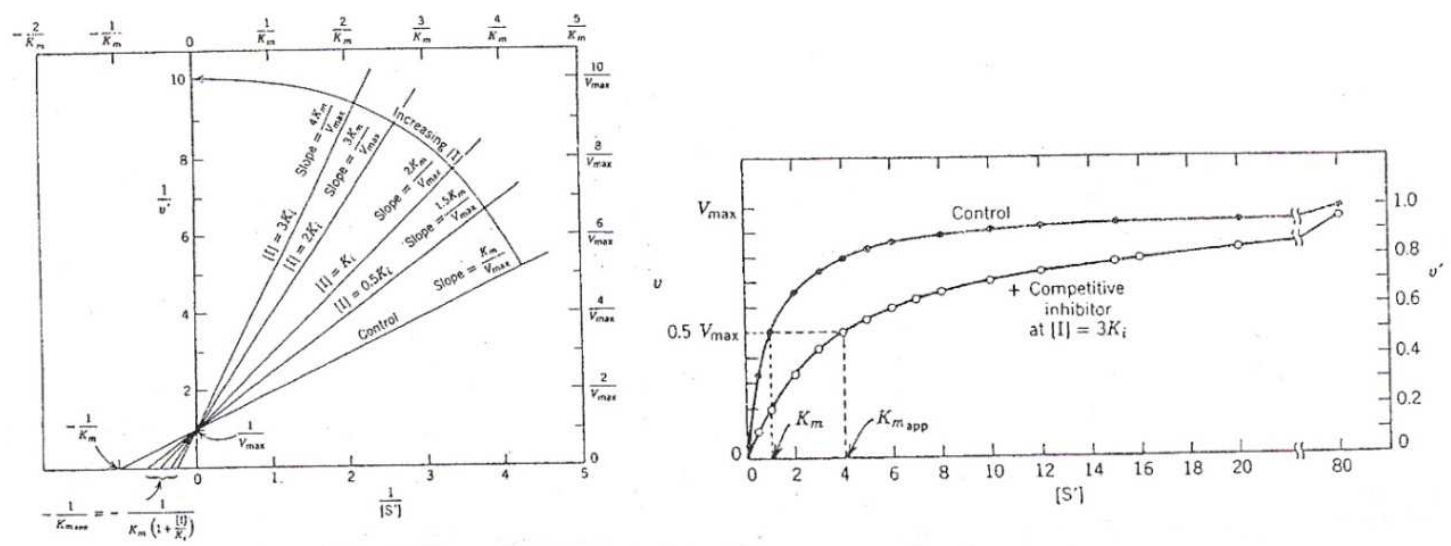

Fig. 17. Graphical determination of $V_{\max }$ and $K_{m}$.

where $\mathrm{J}_{1 \rightarrow 2}$ is the flux from compartment 1 to compartment $2, \mathrm{~J}_{\max }$ is the maximum rate of flux, i.e. the plateau value at saturation of the mediated system, $\mathrm{K}_{\mathrm{m}}$ is the affinity constant and it can be expressed as the permeant 
concentration at which $\mathrm{J}=\mathrm{J}_{\max } \div 2$, and $\mathrm{C}_{1}$ is the concentration of solute in compartment 1 (Fig. 17). The flux expression given in Eq. 19 refers the movement of solute in one direction only, but solutes may move with equal facility in the reverse direction. The net solute

A plot of transport velocity, v, against substrate concentration, $[\mathrm{S}]$, in the presence and in the absence of a fixed concentration of a competitive inhibitor. Also, a Lineweaver-Burk double reciprocal, $1 / \mathrm{v}$ versus $1 /[\mathrm{S}]$, plot in the presence of different fixed concentrations of a competitive inhibitor. Transporter kinetics: $\mathrm{V}_{\max }$ is the constant rate reached when the transporter is completely saturated with the substrate. The slope of the line is $\mathrm{K}_{\mathrm{m}} /$ $\mathrm{V}_{\max }$, the $\mathrm{y}$ intercept is $1 / \mathrm{V}_{\max }$ and the $\mathrm{x}$ intercept is $1 / \mathrm{K}_{\mathrm{m}}$.

After: Michaelis, L. and Menten, M.L. (1913)"Die kinetik der invertinwirkung", Biochem.Z., vol. 49, pp. 333369.

flux is the difference between influx and efflux (Eq.20).

$$
\text { Net flux }=\mathrm{J}_{1} \rightarrow_{2}-\mathrm{J}_{2} \rightarrow_{1}
$$

where 1 and 2 refer to opposite sides of the membrane.

\subsection{Active Transport}

In much the same way that simple diffusion cannot account for the rates of carrier mediated diffusion across membranes, the rate of permeation, and particularly the steady-state distribution of some of the most important physiological substances, defy explanation in terms of spontaneous diffusion. The low intracellular sodium $\left(\mathrm{Na}^{+}\right)$ and high potassium $\left(\mathrm{K}^{+}\right)$concentrations found in red blood cells, and the uptake of a variety of sugars, amino acids and other substrates necessarily involves mediated permeation against electrochemical potential gradients, a coupled energy supply is essential [146,198]. Such transport can only be accomplished at the expense of metabolic energy and an important feature of activetransport systems is that they are all unidirectional in their energy-requiring function.

The standard free energy change for the movement of uncharged molecule from one side a membrane at concentration $\mathrm{C}_{1}$ to the other at concentration $\mathrm{C}_{2}$ is given by the usual equation [199],

$$
\Delta \mathrm{G}=-2.3 \mathrm{RT} \log \mathrm{K}_{\mathrm{eq}}^{\prime}+2.3 \mathrm{RT} \log \frac{\mathrm{C}_{2}}{\mathrm{C}_{1}}
$$

$\mathrm{K}_{\mathrm{eq}}^{\prime}$ a simple diffusion process is unity. That is, at diffusion equilibrium, the concentration of the solute is the same on both sides of the membrane. Thus, $\Delta G$ for the movement of the solute from side 1 to side 2 under nonequilibrium conditions is given by

$$
\Delta \mathrm{G}=2.3 \mathrm{RT} \log \frac{\mathrm{C}_{2}}{\mathrm{C}_{1}}
$$

Eq. 22 gives the free energy of dilution or concentration.
That is, the difference in chemical potential of a solute at two different concentrations. If $\mathrm{C}_{1}$ is greater than $\mathrm{C}_{2}, \Delta \mathrm{G}$ is negative. This says that the molecules of solute will spontaneously move from compartment 1 to compartment 2 (a conclusion we intuitively reach without any equations). The red blood cells have the ability to transport and accumulate certain compounds against large concentration gradient (Hald et al., 1948; Lepke and Passow, 1973; Lew et al., 2003). The $\Delta \mathrm{G}$ for such transport processes is clearly positive and, consequently, energy must be supplied. That is, the uphill transport of a molecule must be coupled somehow to an exergonic reaction in order to make the overall $\Delta \mathrm{G}$ zero or negative. The mechanisms of energy coupling as well as the mechanisms of transport itself are subjects of intensive research.

Active transport systems $\left(\mathrm{Na}^{+} / \mathrm{K}^{+}, \mathrm{Mg}^{2+}, \mathrm{Ca}^{2+}\right.$ pumps) also create and maintain ionic gradients, allowing the cell precise control over its internal physiological environment $[38,200,201]$. One pump, often called the sodium pump, maintains a low $\mathrm{Na}^{+} / \mathrm{K}^{+}$ratio inside the red blood cells in the face of a high $\mathrm{Na}^{+} / \mathrm{K}^{+}$ratio in the intracellular medium $[180,202,203]$, whereas $\mathrm{Ca}^{2+}$ pump maintains the intracellular concentration at a much higher level than that of the extracellular medium [204]. Most transport processes are mediated by specific membrane protein transporters; the term "permease" is often used for such membrane transport systems. Interesting examples of active transport are provided by the distributions of ions across membranes in living red blood cell systems (Table 5). There is direct evidence that the transporter does not move bodily through the membrane, but instead straddles the membrane, part of the molecule being at the outside surface and part at the inside surface of the membrane. For example, the ATP (adenine triphosphate) splitting molecule which transports $\mathrm{K}^{+}$into intracellular medium and $\mathrm{Na}^{+}$out of it against the concentration gradients [205]; the transporter molecules function by actually transporting legands across the lipid membrane as a result of solute-transporter protein conformational changes (Fig. 18).

This active transport system is primarily responsible for maintaining the intracellular $\left[\mathrm{Na}^{+}\right]$and $\left[\mathrm{K}^{+}\right]$at $16 \mathrm{mM}$ and $134 \mathrm{mM}$, respectively, whereas their extracellular concentrations are $140 \mathrm{mM}$ and $4 \mathrm{mM}$, respectively for setting-up and generating the membrane potential. It does this by transporting out of the cell three sodium cations for every two potassium cations transported into the cell. Step 1: One subunit of the protein hydrolyzes the ATP and transfers the $P_{i}$ to an aspartate side chain on another subunit Intracellular $3 \mathrm{Na}^{+}$ions anchored to transporter binding site. Step2: The phosphorylation of one subunit causes a conformational change in the transporter in which the $3 \mathrm{Na}^{+}$ ions are effluxed the extracellular medium. Step 3: While the transporter is outwards facing and its sub unit is still phosphorylated, extracellular $2 \mathrm{~K}^{+}$ions access their binding site. Step 4: The hydrolysis of $\mathrm{P}_{\mathrm{i}}$ bond (dephosphorylation) causes conformation change in the transporter, in which the transporter is inwards facing and the $2 \mathrm{~K}^{+}$ions are influxed. 
The hydrolysis of a single ATP per transport cycle provides sufficient free energy $(\sim-12 \mathrm{kcal}$.mole $)$ to drive the uphill transport of these cations.
Adapted from: Campbell, M.K. and Farrell, S.O. (2006) Biochemistry, $5^{\text {th }}$ edn.p.201. Belmont, CA: Thompson Learning, Inc.

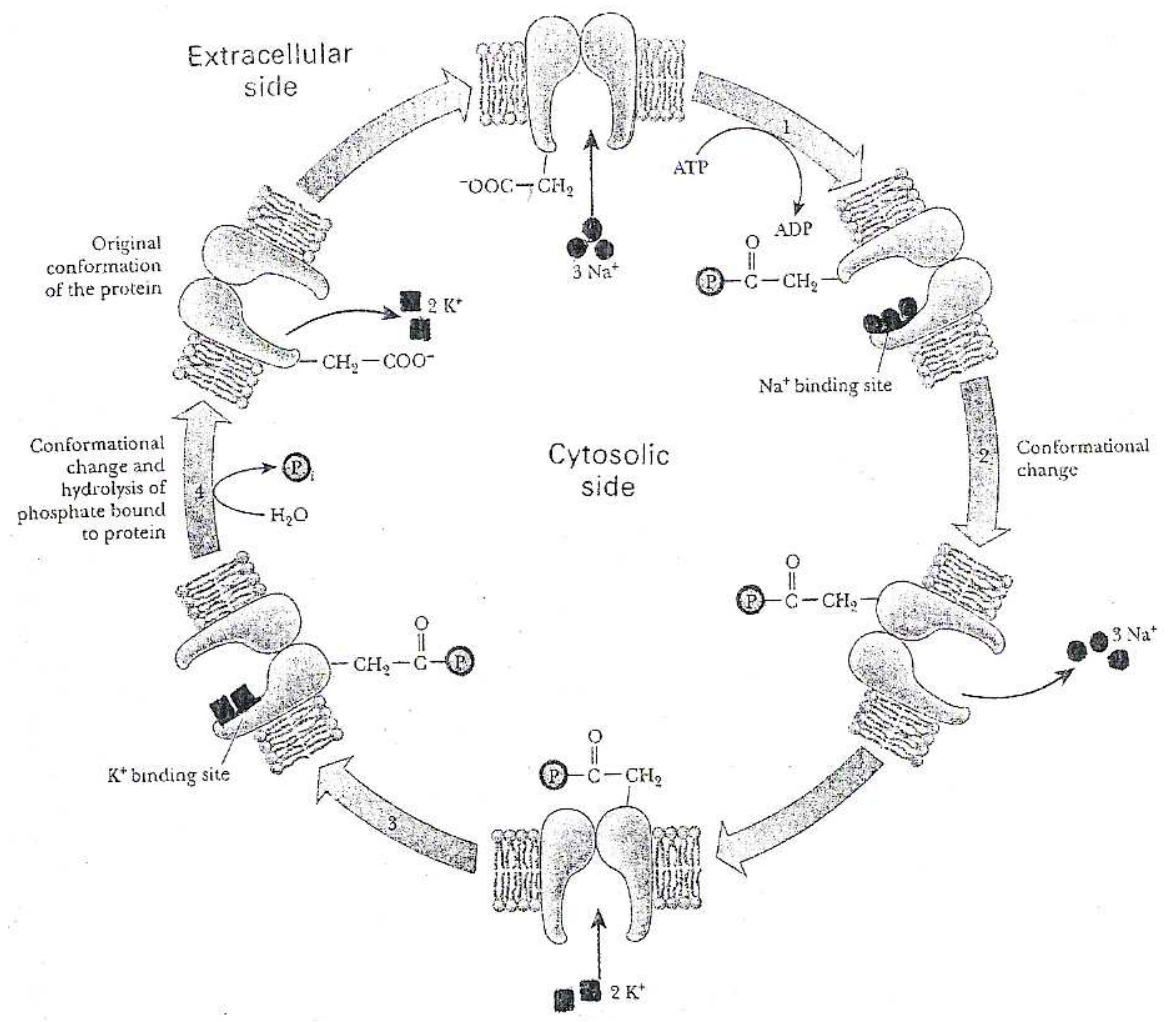

Fig.18. Postulated mechanism of sodium-potassium ion pump.

A number of specific transporters have now been identified, but the precise mechanisms by which they catalyze the transport have not been established as yet.

\section{References}

[1] A.Piperno, S. Galimberti, R.Mariani, S.Pelucchi, G.Ravasi, C.Lombardi, G. Bilo, M. Revera, A. Giuliano, A. Faini, V., Mainini, M. Westerman, T. Ganz, M.G. Valsecchi, G. Mancia and G.Parati (2011) "Modulation of hepcidin production during hypoxia-induced erythropoiesis in humans in vivo: data from the HIGHCARE project", Blood, vol.117 (10), pp.2953-2595.

[2] J. Seifter, A. Ratner and D.Sloane. (2005) Concepts in Medical Physiology. Baltimore, MD: Lippincott Williams \&Wilkins.

[3] A. van Leeuwenhoek (1695) Arcana Natura Detecta. Apud Henricum a Krooneveld: Delphis Batavorum.

[4] J. Swammerdam (1737) Bybel der Nature, in The Book of Nature, Hill, J. (ed.). London: Bookseller C.G. Seyffert.

[5] S.I. Hajdu(2003) "A note from history; the discovery of bloodcells", Annals of Clinical \& Laboratory Science, vol.33, pp.237-238.

[6] J.H. Bennett (1841) The Employment of the Microscope in Medical Studies. Edinburgh: C. Stewart \& Co.
[7] L.S. Beale (1877) The microscope in Medicine. London: J.\& A. Churchill.

[8] G.Schwartz and P.W. Bishop (1958)Moments of Discoveries, Volume 1. New York: Basic Books.

[9] J.R. Porter (1976) "Antony van Leenwenhoek: tercentary of his discovery of bacteria", Bacteriology Review, vol.40(2),pp.260-269.

[10] K. Landsteiner, (1900) "Zur kenntnis der antifermentativen, lytischen und agglutinierenden wirkungen des blutserums und der lymphe", Centralbl f Bakt., vol.27, pp. 253-360.

[11] K.Landsteiner and A.S. Wiener (1940) “An agglutinable factor in human blood recognized by immune sera for Rhesus blood", Proc. Soc. Exp. Biol. Med., vol.43, pp.223224.

[12] A. von Decastello and A. Sturli (1902) "Ueber die isoagglutinine im serum gesunder und kranker menschen", Mfinch med Wschr, vol.49, pp.1090-1095.

[13] J. Jansky (1907) "Haematologicke studie u psychotiku: etudes hematologiques dans les maladies", Sborn Klin, vol.8, pp.85-135.

[14] W.M. Watkins (2001) "The ABO blood group system: historical background”, Transfus Med., vol.11, pp.243-265.

[15] L. Dean (2005) Blood Groups and Red Cell Antigens. Bethesda,MD: National Centre for Biotechnology Information. 
[16] R. Ottenberg and D.Haliski (1913) "Accidents in transfusion: their prevention by prevention by preliminary blood examinations", JAMA, vol.61, pp.2138-2140.

[17] P.L. Mollison (2000) "The introduction of citrate as an anticoagulant for transfusion and of glucose as a red cell preservative", Br.J.Haematol., vol.108, pp.13-18.

[18] M.F. Perutz, M.G. Rossman, A.F. Cullis, Muirhead, H. G. Will and A.C.T. North (1960) "Structure of haemoglobin: a three-dimensional fourier synthesis at 5.5-.ANG. resolution, obtained by X-ray analysis", Nature, vol. 185, pp. 416-422.

[19] L. Kaestner, W.Tabellion, E. Weiss, I.Bernhardt, and P. Lipp (2006) "Calcium imaging of individual erythrocytes: problems and approaches", Cell Calcium, vol.39, pp.13-19.

[20] L. Kaestner (2011) "Cation channels in erythrocyteshistorical and future perspective", The Open Biology Journal, vol.4,pp.27-34.

[21] W.F. Ganong (2003) Review of Medical Physiology, $21^{\text {st }}$ edn. New York:_McGraw-Hill Lang. [75] Geers, C. and Gros, G. (2000)"Carbon dioxide transport and carbonic anhydrase in blood and muscle", Physiol Review, vol. 80 (2), pp.681-715.

[22] I.L. Weissman, D.J. Anderson and F.Gage (2001) " Stem and progenitor cells: origins, phenotypes, lineage commitments, and transdifferentiations", Annu Rev Cell Dev Biol., vol.17, pp. 387-403.

[23] J. Macleod (1977) Davidson's Principles and Practice of Medicine, 12th edn. Edinburgh: Churchill.

[24] J. Pallis, and G.B. Segel (1998) "Development biology of erythropoiesis", Blood Review, vol.12 (2), pp.106-114.

[25] I. Baciu and L.Ivanof (1984) "Erythropoietin interaction with the mature red cell membrane, Ann.N.Y.Acad.Sci" vol.414,pp. 66-72.

[26] W. Bartley, L.M. Birt and P. Banks (1968) The Biochemistry of the Tissues, London: John Wiley \& Sons Ltd.

[27] D.W. Golde, N. Bersch, S.G. Quan and A.J. Lusis (1980) "Production of erythroid- potentiating activity by a human T-lymphoblast cell line", Proc. Nati. Acad. Sci. USA, vol. 77, No. 1, pp. 593-596.

[28] J.D. Bauer, P.G. Ackermann and G.Toro (1974) Clinical Laboratory Methods, $8^{\text {th }}$ edn. St.Louis, MO: The C.J.Mosby Company.

[29] J.W. Harris and R.W. Kellermeyer (1974) The Red CellProduction, Metabolism, Destruction: Normal and Abnormal.Cambridge, MA: Harvard University Press.

[30] F. Ajmar, , C. Garre, M. Sessarego, R. Ravazzolo, R. Barresi, G.B. Scarra and M.Lituania (1983) "Expression of erythroid acetylcholineesterase in the K-562 leukemia cell line", Cancer Res., vol.43, pp.5560-5563.

[31] K.J. Halbhuber, C. Lemke, D.Stibenz and W. Linss, (1984) "Activation of acetylcholine esterase (ACHE) as a sign for erythrocyte membrane alteration", Exp.Pathol, vol.25 (1), pp.35-44.

[32] S. Trubowitz and B.Masek (1968) "A histochemical study of the reticuloendothelial system of human marrow-it's possible transport role", Blood, vol. 32 (4), pp. 610-628.

[33] R.M. Cohen, R.S. Franco, P.K. Khera, E.P. Smith, C.J.
Lindsell, P.J. Ciraolo, M.B. Palascak and C.H. Joiner (2008) "Red cell life span heterogeneity in hematologically normal people is sufficient to alter HbA1c", Blood, vol.12 (10), pp.4284-4291.

[34] N.T. Berlin, M. Beeckmans, P.J. Elmlinger and J.H. Lawrence, (1957) "Life span of red blood cell", J.Lab.Clin. Med., vol.50, p.558.

[35] J.C. Ellory and J.D. Young (1982) Red Cell Membranes - A Methodological Approach. London: Academic Press.

[36] R. Whittam (1964) Transport and Diffusion in Red Blood Cells. London: Edward Arnold (publishers) Ltd.

[37] H.B. Sutton and N.S. Moore (1944) "The diagnosis and treatment of congenital hemalotic (spherocytic) jaundice: report of a case with unusual blood findings altered by liver therapy", Ann. Intern. Med., vol.21 (4), pp. 698-708.

[38] I. Bernhardt and J.C. Ellory (2003) Red Cell membrane Transport in Health and Disease. Berlin: Springer-Verlag.

[39] Y. Yawata (2003) Cell Membrane: The Red Blood Cell as a Model. Weinheim, Germany: Wiley-VCH GmbH \& Co.KGaA.

[40] F.J.W. Roughton (1963) "Kinetics of gas transport in the blood”, Br.Med.Bull, vol.19 (1), pp.80-89.

[41] G.R. Cokelet and H.J. Meiselman (1968) "Rheological comparison of hemoglobin solutions and erythrocyte suspensions", Science, vol.162, pp.275-277.

[42] R.A.B. Holland (1969) " Rate at which $\mathrm{CO}$ replaces $\mathrm{O}_{2}$ from $\mathrm{O}_{2} \mathrm{Hb}$ in red cells of different species", Respiratory Physiology, vol.7 (1), pp.43-63.

[43] W. Lathem and W.E. Worley (1959) " The distribution of extracorpuscular hemoglobin in circulating plasma", J.Clin.Invest, vol.38 (3), p.474-483.

[44] H.C. Wilson (1923) "The effect of carbon dioxide and acetic acid on the osmotic pressure of haemoglobin", Biochem. J., vol.17 (1), pp.59-71.

[45] J.H. Green (1978) Basic Clinical Physiology, $3^{\text {rd }}$ edn. Oxford: Oxford University Press.

[46] P.A. Fortes (1977) "Anion movement in red blood cells", in Membrane Transport in Red Cells, Ellory, J.C. and Lew, V.L.(eds.), pp.175-195. London: Academic Press.

[47] A.J. Vander, J.H. Sherman and D.S. Luciano (1978) Human Physiology, $2^{\text {nd }}$ edn. New Delhi: Tata McGraw Hill Ltd.

[48] R. Benesch and R.E. Benesch (1967) “ The effect of organic phosphates from the human erythrocyte on the allosteric properties of hemoglobin", Biochem. Biophys. Res. Comm., vol.26 (2), pp.162-167.

[49] K. Imaizumi, K.Imai and I.Tyuma (1982) "Linkage between carbon dioxide binding and four-step oxygen binding to hemoglobin", J.Mol.Biol, vol.159 (4), pp.703-719.

[50] R.E. Dickerson and I.Geis (1983) Haemoglobin: Structure, Function, Evolution and Pathology. San Francisco, CA: The Benjamin/Cummings Pub., Inc.

[51] R.C. Darling and F.J.W. Ranghton (1942) "Effect of methemoglobin on equilibrium between oxygen and hemoglobin", Am. J. Physiol, vol.137, pp.56-68. 
[52] R.W. Hill (1976) Comparative Physiology of Animals. New York: Harper \& Row Publishers.

[53] A. White, P. Handler and E. Smith E. (1973) Principles of Biochemistry, $5^{\text {th }}$ edn. Tokyo: McGraw-Hill Kogakusha Ltd.

[54] S. Tomita and A.Riggs (1971) "Studies of the interaction of 2, 3-diphosphoglycerate and carbon dioxide with hemoglobins from mouse, man, and elephant", J.Biol.Chem, vol.246, pp.547-554.

[55] R.J. Tanis, R.E. Tashian and Y.S.L. Yu (1970) “ Properties of carbonic anhydrase isozymes isolated from porcine erythrocytes", J. Biol. Chem, vol.245, pp.6003-6009.

[56] B.K. Vallee and A. Galdes, (1984)“"The metallobiochemistry of zinc enzymes”, Adv. Enzymol, vol.56, pp.283-430.

[57] J.C. Ellory, H. Guizouran, F. Borgese, L.J. Bruce, R.J. Wilkins and G.W. Stewart (2009) "Leaky $\mathrm{Cl}^{-} \mathrm{HCO}_{3}$ " exchangers: cation fluxes via modified AE1", Phil.Trans.R. Soc.B, vol.364, pp.189-194.

[58] C.J. Davidson, E.G. Tuddenham and J.H. McVey (2001) "450 million years of hemostasis", J.Thromb. Haemost., vol.1,pp.1487- 1494.

[59] K.A. Tanaka, N.S. Key and J.H. Levy (2009) "Blood coagulation: hemostasis and thrombin regulation", Anesthesia \& Analgesia, vol.108(5), pp.1433-1446.

[60] K. Landsteiner (1961) "On agglutination of normal human blood", Transfusion, vol.1, pp. 5-8.

[61] M.G. Angelos and G.C. Hamilton (1986) "Coagulation studies: prothrombin time, partial thromboplastin time, bleeding time", Emerg.Med.Clin. North. Am., vol. 4(1), pp.05-113.

[62] N.C. Hughes-Jones and B.Gardener (2002) "Historical review red cell agglutination: the first description by Creite (1869)and further observations made by Landois (1875) and Landsteiner (1901)", Br.J.Haematol, vol.119, pp.889-893.

[63] K.E.Barrett, S.M. Barman, S.Boitano and H Brooks (2012) Ganong's Review Medical Physiology, $24^{\text {th }}$ edn. New York: McGraw-Hill Professional.

[64] W.L. Nichols and J.W. Bowie (2001) A History of Blood Coagulation. Rochester, MN: Mayo Clinic Foundation.

[65] A.T. Nurden and J.N. George (2005) Inherited Abnormalities of Platelets Membranes: Glanzman Thrombasthenia, Bernard-Soulier Syndrome, and Other Disorders, in Hemastasis and Thrombosis, Basic Principles \& Clinical Practice, Colman, R.W., Marder, V.J., Clowes, A.W., George, J.N. and Goldhaber, A.Z. (eds.), pp.987-1010. Philadelphia, PA: VI.Lippincott, Williams \& Wilkins.

[66] C. Chaimoff, D.Creter and M.Djaldetti (1978) "The effect of $\mathrm{pH}$ on platelet and coagulation factor activities", Am.J.Surg., vol. 136(2), pp. 257-259.

[67] G.L. Dale (2005) "Coated-platelets: an emerging omponent of procoagulant response", J.Thromb. Haemost., vol. 3(10), pp. 2185-2192.

[68] J. Dias , M. Gumenyuk , H.Kang, M.Vodyanik,, J. Yu, J.A.Thomson and I.I. Slukvin (2011) "Generation of red blood cells from human induced pluripotent stem cells", Stem Cells Dev., vol. 20 (9), pp.1639-1547.
[69] P. Fantle and H.A. Ward (1965) "Human fibrinogen derived from phosphorus determinations", Biochem. J., vol.96, pp.886-889.

[70] J.Y. Chang (1986) "The structure and proteolytic specifications of autolysed human thrombin", Biochem. J., vol.240 (3),pp.797-802.

[71] W.W. Duke (1910) "The relation of blood platelets to hemorrhagic disease", J.Am.Med.Ass, vol.55, pp.1185-1193.

[72] A.J Hellem, C.F. Borchgrevink and S.B. Ames (1961) "The role of red cells in haemostasis: the relation between haematocrit , bleeding time and platelet adhesiveness", Br.J.Haematol., vol.7, pp. 42-49.

[73] V.T. Turitto and H.J. Weiss (1980) "Red blood cells: their dual role in thrombus formation", Science, vol. 207, pp.541543.

[74] S. Valles, M.T. Santos, J.Aznar, A.J. Marcus, V. MartinezSales, M. Portoles, M.J. Broekman and L.B. Safier, (1991) "Erythrocytes metabolically enhance collagen- induced platelet responsiveness via increased thromboxane production, adenosine diphosphate release and recruitment", Blood, vol.78, pp.154-162.

[75] M.T. Santos, J.Valles, J. Aznar, A.J. Marcus, M.J. Broekman and L.B. Safier (1997) "Prothombotic effects of erythrocytes on platelet reactivity: reduction by aspirin", Circulation, vol.95, pp.63-68.

[76] D.A. Andrews, and P.S.Low (1999) "Role of red blood cells in thrombosis", Curr.Opin.Hematol., vol.6(2), pp.76-82.

[77] L. Kaestner, W.Tabellion, P.Lipp and I. Bernhardt (2004) "Prostaglandin E2 activates channel-mediated calcium entry in human erythrocytes: an indication for a blood clot formation supporting process", Thromb. Haemost., vol.92, pp.1269-1272.

[78] D. Mori, K. Yano, K. Tsubota, T. Ishikawa, S. Wada and T.Yamaguchi (2008) "Computational study on effect of red blood cells on primary thrombus formation", Thrombosis Research, vol.123 (1), pp.114-121.

[79] J.Y. Noh, K.M. Lim, O.N. Bae, S.M. Chung, S.W. Lee, K.M. Joo, S.D. Lee and J.H. Chung (2010) "Procoagulant and prothrombotic activation of human erythrocytes by phosphatidic acid", Am.J. Physiol: Heart Circ. Physiol., vol.299, pp.347-355

[80] D. L. Nelson and M.M.Cox (2008) Lehninger Principles of Biochemistry, $5^{\text {th }}$ edn. New York: W.H.Freeman and Company.

[81] F.J. Lionetti (1974) "Pentose phosphate pathway in human erythrocytes", in Cellular and Molecular Biology of Erythrocytes, Yoshikawa, H. and Rapoport, S.M. (eds.), pp.143-166. Tokyo: University of Tokyo Press.

[82] S.G. Sullivan and A.Stern (1984) "Glucose metabolism of oxidatively stressed human red blood cells incubated in plasma or medium containing physiologic concentrations of lactate, pyruvate and ascorbate", Biochem. Pharmacol., vol. 33(9), pp.1417-1421.

[83] D.Galleman and P. Eyer (1993) "Effects of phenacetin metabolites 4-nitrosophenol on glycolysis and pentose pathway in human red blood cells", Biol.Chem. Hoppe Seyler, vol. 4(1), pp.37-49. 
[84] M.A. Milanick and R.B. Gunn (1982) "Proton-sulfate cotraosnport mechanism of $\mathrm{H}^{+}$and sulfate addition to the chloride transporter of human red blood cells", J.Gen. Physiol., vol.79, pp.87-113.

[85] V. de Bari and A.Bennun (1984) "Regulation of the pentose phosphate pathway in the human erythrocyte", Biophys. J., vol.45 (2), p.212.

[86] R. Sasaki and H.Chiba (1983) "Role and induction of 2, 3bisphosphoglycerate synthase”, Mol. Cell Biochem., vol.53, pp. 247-256.

[87] E.R. Jaffe (1974) "The formation and reduction of methemoglobin in human erythrocytes", in Cellular and Molecular Biology of Erythrocytes, Yoshikawa, H. and Rapoport, S.M. (eds), pp.345-376. Tokyo: University of Tokyo Press.

[88] R.B. Gunn (1973) "Recent Advances in Membrane Metabolic Research", in Erythrocytes, Thrombocytes, Leukocytes, Gerlach, E., Moser, K., Deutsch, E. and Willmanns, W. (eds), pp.77-81. Stuttgart, Germany: Georg Thieme.

[89] O.H. Lowry, N.J. Rosenbrough, A.L. Farr and R.J. Randall (1951) "Protein measurement with the Folin-phenol reagent", Biol. Chem., vol.193, pp.265-275.

[90] J.T. Dodge, C. Mitchelland D.J. Hanahan (1963) "The preparation and chemical characteristics of hemoglobin-free ghosts of human erythrocytes", Arch. Biochem., vol.100, pp.119-130.

[91] T.L. Steck and J.A. Kant (1974) "Preparation of Impermeable Ghosts and Inside-out Vesicles from Human Erythrocyte Membranes", in Methods in Enzymology, Fleischer, S. and Packer, S. (eds.), vol. 31, pp.172-180.

[92] C.A. Seymour, S. Muallen and V.L. Lew (1982) "Preparation of Inside-out Vesicles from Red Blood Cells in One Step", in Red Cell Membranes - A Methodological Approach, Ellory, J.C. and Young, J.D. (eds.), pp.219-222. London: Academic Press.

[93] P.M. Hilarius, I.G. Ebbing, D.W. Dekkers, J.W. Lagerberg, D. de Korte and A.J. Verhoeven (2004) "Generation of singlet oxygen induces phospholipid scrambling in human erythrocytes", Biochemistry, vol.43, pp.4012-4019.

[94] M. Minetti, L.Agati and W. Malorni (2007) "The microenvironment can shift erythrocytes from a friendly to a harmful behavior: pathogenic implications for vascular diseases", Cardiovasc. Res., vol.75, pp. 21-28.

[95] W.D. Stein (1972) "The mechanism of sugar transfer across erythrocyte membranes", Ann. N.Y. Acad. Sci.USA,vol.195,pp.412-428.

[96] J.A.F. Op den Kamp (1981) The Asymmetric Architecture of Membranes, in New Comprehensive Biochemistry, Finean, J.B. and Michell, R.H. (eds.), pp.83-126. Amsterdam: Elsevier.

[97] A. Herrmann and P.Müller (1986) "A model for the asymmetric lipid distribution in the human erythrocyte membrane", Bioscience Reports, vol.6 (2), pp.185-190.

[98] N. Mohandas and P.G. Gallagher (2008) "Red cell membrane: past, present and future", Blood, vol.112 (10), pp.3939-3948.
[99] L.L.M. van Deenen, J. de Gier, U.M.T. Houtsmuller, A.Montfoort and E.Mulder (1963) "Dietary Effects on the Lipid Composition of Biomembranes", in Biochemical Problems of Lipids, Frazer, A.C. (ed.), pp. 404-414. Amsterdam: Elsevier.

[100] G. Fairbanks, T. L. Steck and D. F. H Wallach (1971) "Electrophoretic analysis of the major polypeptides of the human erythrocyte membrane", Biochemistry, vol.10, pp.2606-2617.

[101] T.L. Steck G. Fairbanks and D.F.H. Wallach (1971) "Disposition of the major proteins in the isolated erythrocyte membrane. Proteolytic dissection", Biochemistry, vol.10, pp. 2617-2624.

[102] M.J. Tanner, P.G. Martin and S.High (1988) "The complete amino acid sequence of the human erythrocyte membrane anion-transport protein deduced from the cDNA sequence ", Biochem. J., vol.256 (3), pp.703-712.

[103] R.L. Juliano (1973) "The proteins of the erythrocyte membrane", Biochem. Biophys. Acta., vol.300, pp.341-378.

[104] J. Lenard and S.J. Singer (1966) "Protein conformation in cell membrane preparations as studied by optical rotatory dispersion and circular dichroism", Proceedings of the National Academy of Sciences, vol.56, pp.1828-1835.

[105] S.J. Singer and G. L. Nicolson (1972) "The fluid mosaic model of the structure of cell membranes", Science, vol. 175 pp. 720-731.

[106] T.L. Steck (1974) "The organization of proteins in the human red blood cell membrane", J. Cell Biol., vol.62 (1),pp.1-19.

[107] S.E. Lux (1979) "Dissecting the red cell membrane skeleton”, Nature (London), vol.281, pp.426-429.

[108] S.C. Rastogi (2010) Biochemistry, $3^{\text {rd }}$ edn. New Delhi: Tata McGraw-Hill Education.

[109] G. Fairbanks and J. Avruch, (1972) "Four gel systems for electrophoretic frantionation of membrane proteins using ionic detergents", J.Supramol Struct., vol.1, p.66-75.

[110] C.J. Brock and M.J.A. Tanner (1986) "The human erythrocyte anion-transporter protein”, Biochem, J., vol.235, pp.899-901.

[111] M.R. Deziel, C.Y. Jung and A.Rothstein (1985) "The topology of the major band 4.5 protein component of the human erythrocyte membrane: characterization of reactive cysteine residue", Biochim. Biophys. Acta, vol.819 (1), pp.83-92.

[112] R.E. Jenkins and M.J.A. Tanner (1977) "Ionic-strengthdependent structure of the major protein of the human erythrocyte membrane", Biochem. J., vol.161, pp.131-138.

[113] S. Pikula, J. Bandorowicz-Pinkula, S. Awasthi, and Y.C. Awasthi (1996) "Differential staining of human erythrocyte membrane proteins by coomassie and silver: implications in the assessment of homogeneity of membrane proteins", Biochem. Arch., vol.12, pp.237-243.

[114] D.A. Butterfield, B.T. Farmer and J.B. Feix, (1984) "Induced alterations in the physical state of sialic acid and membrane proteins in human erythrocyte ghosts: implications for the topology of the major 
sialoglycoprotein", Ann. N.Y. Acad Sci., vol.414, pp.169179 .

[115] T.J. Mueller and M.Morrison (1975) "Transmembrane proteins in the plasma membrane of normal human erythrocytes. Evaluation employing lactoperoxidase and proteases", Biochemistry, vol.14 (25), pp. 5512-5516.

[116] Y. Abe, T. Chaen, X.R. Jin, T.Hamasaki and N. Hamasaki (2004) "Massspectrometric analyses of transmembrane proteins in human erythrocyte membrane", J.Biochem, vol.136 (1), pp.97-106.

[117] Z.I. Cabantchik, P.A. Knauf and A.Rothstein (1978) "The anion transport of the red blood cell", Biochim.Biophys.Acta vol.515, pp. 239-302.

[118]H. Furthmayr (1978) "Structural comparison of glycophorins and immunochemical analysis of genetic variants", Nature, vol. 271(5645), pp.519-524.

[119] M. Tomita, H.Furthmayr and V.T. Marchesi (1978) " Primary structure of human erythrocyte glycophorin A. Isolation and characterization of peptides and complete amino acid sequence", Biochemistry, vo.17 (22), pp.47564770 .

[120] G. Guidotti (1972) “Membrane proteins",Ann. Rev. Biochem., vol.41, pp.731-752.

[121] L.K.Drickamer (1978) "Orientation of the Band 3 polypeptide from human erythrocyte membranes. Identification of NH2-terminal sequence and site carbohydrate attachment", J.Biol.Chem., vol.253 (20), pp.7242-7248.

[122] C.G. Gahmberg, G. Myllyla, J. Leikola, A. Pirkola, and S. Nordling (1976) "Absence of the major sialoglycoprotein in the membrane of human En(a-) erythrocytes and increased glycosylation on band 3", J.Biol. Chem., vol.251, pp.61086616.

[123] A.Boodhoo and R.A.F. Reithmeier (1984) "Characterization of the matrix-bound band 3, the anion transport protein from human erythrocyte membranes", J.Biol.Chem, vol. 259 (2), pp.786-790.

[124] M.J.A. Tanner and D.H. Boxer (1972) "Separation and some properties of the major proteins of the human erythrocyte membrane", Biochem. J., vol.129, pp.333-347.

[125] M. Ramjeesinhg, A. Gaarn and A.Rothstein (1984) “ Pepsin cleavage of band 3 produces its membrane-crossing domain, II”, Biochim. Biophys. Acta, vol.769 (2), pp.381-389.

[126] S. Gordon and G.B. Ralston (1990) "Solubilization and denaturation of monomeric actin from erythrocyte membranes by p-mercuribenzenesulfonate", Biochim. Biophys. Acta, vol.1025 (1), pp.43-48.

[127] R. Khanna, S.H. Chang, S. Andrabi, M. Azam, A. Kim, A. Rivera, C. Brugnara, P.S. Low, S.C. Lin and A.H. Chishti (2002) "Headpiece domain of dematin is required for the stability of the erythrocyte membrane", Proc. Natl. Acad. Sci.USA, vol. 99 (10), pp. 6637-6642.

[128] R.A.F. Reithmeier and A.Rao (1979) "Reactive sulfhydryl groups of the band 3 polypeptide from human erythrocyte membranes", J.Biol.Chem., vol.254 (13), pp. 6151-6155.

[129] M.L. Jennings, M.Adams-Lackey and G.H. Denney (1984)
"Peptides of human erythrocyte band 3 protein produced by extracellular papain cleavage", J.Biol.Chem, vol.259 (7), pp.4652-4660.

[130] S. Perrotta, A. Borriello, A. Scarloni, , L. de Franceschi, A.M. Brunati, F. Turrini, V.E.M. Del Giudice, B. Nobili, M.L. Conte, F. Rossi, A. Lolascon, A. Donella-Deena, V. Zoppia, V. Poggi, W. Anong, P. Low, N.Mohandas and F.D. Ragione (2005) "The N-terminal 11 amino acids of human erythrocyte band 3 are critical for aldolase binding and protein phosporylation: implications for band 3 function", Blood, vol.106 (13), pp.4359-4366.

[131] J.M. Salhany (1996) "Allosteric effects stilbenedisulfonate binding to band 3 protein (AE1)", Cell Mol.Biol., vol.42 (7), pp. 1065-1096.

[132] C.H. Huang (1977) "A structural model for cholesterolphosphotidylcholine complexes in bilayer membranes", Lipids, vol. 12 (4), pp.348-356.

[133]B. Deuticke (1977) "Properties and structural basis of simple dif- fusion pathways in the erythrocyte membrane", Rev. Physiol. Biochem. Pharmacol., vol.78, pp. 1-98.

[134] M.S. Bretscher (1985) "The molecules of the cell membrane", Sci. Am., vol.253 (4), pp.100-108.

[135] P.F. Franck, D.T. Chiu, J.A. Op den Kamp, B. Lubin, L.L. van Deenan and B.Roelosfsen (1983) "Accelerated transbilayer movement of phosphatidylcholine in sickle erythrocyte. A reversible process", J. Biol.Chemistry, vol.258, pp.8436-8422.

[136] R.K. Crane (1977) "The gradient hypothesis and other models of carrier-mediated active transport", Rev.Physiol. Biochem. Pharmacol., vol.78, pp.99-159.

[137] K. A. Fisher (1976) "Analysis of membrane halves: cholesterol”, Proc. Natl. Acad. Sci. U. S. A, vol.73, pp.173177.

[138] J.S. Wiley and R.A. Cooper (1975) "Inhibition of cation cotransport by cholesterol enrichment of human red cell membranes", Biochim. Biophys. Acta., vol.413, pp. 425-431.

[139] R.F.Zwaal, P. Comfururius and E.M. Bevers (2005) "Surface exposure of phosphatidylserine in pathological cells", Cell Mol.Life Sc., vol.62, pp.971-988.

[140] F.A. Kuypers, S.K. Larkin, J.J. Emeis and A.C. Allison (2007) "Interaction of an annexin $v$ homodimer (diannexin) with phosphatydlserine on cell surfaces and consequent antithrombotic activity", Thromb. Haemost., vol.97, pp.478486.

[141] D. Chapman, W.E. Peel, B.Kingston and T.H. Lilly (1977) "Lipid phase transitions in model biomembranes: the effect of ions on phosphatidylcholine bilayers", Biochim. Biophys. Acta, vol. 464 (2), pp.260-275.

[142] J. Seelig and A.Seelig (1980) "Lipid conformation in model membranes and biological membranes", Q.Rev.Biophys., vol.13, pp.19-61.

[143] D. Chapman (1982) "Protein-lipid interaction in model and natural biomembranes", Biological Membranes, vol.4, pp.179-229.

[144] G. Wegner, C. Tanner, D. Maretzki and W.Schossler. (1984) "Immunoglobulin G binding to human erythrocytes", 
Biomed. Biochim. Acta 43:179-186.

[145] W.D. Stein (1967) The Movement of Molecules across Cell membranes. New York: Academic Press.

[146] M.D. Houslay and K.K. Stanley (1982) Dynamics of Biological membranes. Chichester, West Wessex: John Wiley \& Sons.

[147] P.A. Maguire and I.W. Sherman (1990) "Phospholipid composition, cholesterol content and cholesterol exchange in Plasmodium falciparum-infected red cells", Mol Biochem Parasitol., vol. 38 (1), pp.105-112.

[148] R. Heinrich, M. Brumen, A. Jaeger, P. Müller and A.Herrmann (1997) "Modeling of phospholipid translocation in the erythrocyte membrane: a combined kinetic and thermodynamic approach",. J. Theor. Biol., vol. 185 , pp.295-312.

[149] E. Wodtke (1983) " On adaptation of biomembranes to temperature: membrane dynamics and membrane function", J. Therm. Biol. Vol.8, pp.416-420.

[150] D.E. Golan, S.T. Furtlong, C.S. Brown and J.P. Caulfield 1988)"Monopalmitoylphosphatidylcholine incorporation into human erythrocyte ghost membranes causes protein and lipid immobilization and cholesterol depletion", Biochemistry, vol.27 (8), pp. 2661-2667.

[151] P. Müller and A. Hermann (2002) "Rapid transbilayer movement of spin-labeled steroids in human erythrocytes and in liposomes", Biophysical J., vol. 82, pp.1418-1428.

[152] V. Fowler and D.Branton (1977) “ Lateral mobil-ity of human erythrocytes integral membrane pro-teins", Nature (London), vol.268, pp.23-27.

[153] R.J. Cherry (1979) " Rotational and lateral diffusion of membrane proteins", Biochim. Biophys. Acta, vol.559, pp.289-327.

[154] P. Sche, C. Vera and L.A. Sung (2011) "Intertwined $\alpha \beta$ spectrin meeting helical actin protofilament in the erythrocyte membrane skeleton: wrap-around vs. pointattachment", Ann.Biomed.Eng., vol. 39 (7), pp.1984-1993.

[155] L. Tilley, W.H. Sawyer, J.R. Morrison, N.H. Fidge (1988) "Rotational Diffusion of human lipoproteins and their receptors as determined by time-resolved phosphorescence anisotropy", J. Biol. Chem., vol. 263 (33), pp.17541-17547.

[156] T. Pomorski, P. Müller, B. Zimmermann, K. Burger, P.F. Devaux and A.Hermann (1996) "Transbilayer movement of fluorescent and spin-labeled phospholipids in the plasma membrane of human fibroblasts: a quantitative approach", J.Cell Science, vol.109, pp.687-698.

[157] P. F. Devaux, P.Fellmann and P.Herve (2002) “ Investigation on lipid asymmetry using lipid probes. Comparison between spin-labeled lipids and fluorescent lipids", Chem. Phys. Lipids, vol. 116, pp. 115-134.

[158] P.A. Leventis and S.Grinstein (2010) "Distribution and function of phosphatidyl serine in cellular membranes", Ann.Rev. Biophys., vol.39, pp. 407-427.

[159] N.L. Hiller, T. Akompong, J.S. Morrow, A.A. Holder and K. Haldar (2003) " Identification of a stomatin orthologue in vacuoles induced in human erythrocytes by malaria parasites. A role for microbial raft proteins in apicomplexan vacuole biogenesis", J.Biol.Chem, vol.278 (48), pp.4841348421 .

[160] C. Bracho, I. Dunia, M. Romano, G. Raposo, M. de la Rosa,E.L. Benedetti . and H.A. Pérez (2006) "Caveolins and flotillin-2 are present in the blood stages of Plasmodium vivax", Parasitol Res., vol.99 (2), pp.153-159.

[161] V. Michel and M.Bakovic (2007) "Lipid rafts in health and disease”, Biol.Cell, vol. 99, pp. 129-140.

[162] E. Brown, L. Hooper, T. Ho and H.Gresham (1990) "Integrin-associated protein: a $50 \mathrm{kD}$ plasma membrane antigen physically and functionally associated with integrins", Cell Biol., vol. 111 (6), pp.2785-2794.

[163] G. Benga, V.I.Pop, O.Popescu, M.Ionescu and V.Michele (1983) "Water exchange through erythrocyte membranes: nuclear magnetic resonance studies on the effects of inhibitors and of chemical modifications of human membranes", J. Membr Biol, vol. 76, pp.129-137.

[164] E. Brown (2001) "Integrin-associated protein (CD47): an unusual activator of $\mathrm{G}$ protein signaling”, J.Clin.Invest., vol. 107 (12), pp. 1499-1500.

[165] U.V. Lassen (1977) Electrical Potential and Conductance of the Red Cell membrane, in Membrane Transport in Red Blood Cells, Ellory, J.C. and Lew, V.L. (eds), pp. 137-172. London: Academic Press.

[166] T.Theorell (1959) "Experiments on oscillation transport phenomena in artificial membranes", J.Gen. Physiol, vol.42, pp. 831-845.

[167] R.I. Macey (1984) "Transport of water and urea in red blood cells", Am.J.Physiol., vol. 246 (3), pp. c195-C203.

[168] B.E. Goodman (2002) "The transport of small molecules across cell membranes: water channels and urea transporters", Adv. Physiol. Edu. vol. 26 (3), pp. 146-157.

[169] S. Glasstone (1962) Text Book of Physical Chemistry, $2^{\text {nd }}$ edn. London: Macmillan and Co. Ltd.

[170] A. Fick (1855) “On liquid diffusion”, Philos. Mag .J. Sci, vol. 10 , pp. $30-39$.

[171] W.F. Smith and J.Hashemi (2006) Foundations of Materials Science and Engineering, 4th edn. Boston, MA: McGrawHill.

[172] I.C. West (1983) The Biochemistry of Membrane Transport. London: Chapman and Hall.

[173] D.D. van Slyke, H. Wu and F.C. McLean (1923) "Studies of gas and electrolyte equilibria in the blood.V.Factors controlling the electrolyte and water distribution in the blood", J. Biol. Chem., vol.56, pp.765-849.

[174] A. Rothstein, Z.I. Cabantchik and P.A. Knauf (1976) "Mechanism of anion transport in red blood cells: role of membrane proteins", Fed. Proc., vol.35, pp.3-10.

[175]A. Einstein (1906)"Eine neue bestimmung der molecküldimensionen”, Ann.Phys., vol.19, pp.289-306.

[176] K.J. Laidler (1978) Physical Chemistry with Biological Applications. Menlo Park, CA: The Benjamin/Cummings Publishing Co., Inc.

[177] C.R. Wilke and P.Chang (1955, June) "Correlation of 
diffusion coefficients in dilute solutions", A.I.Ch.Eng.Journal, pp.264-270.

[178] K.Smith (1971) Mechanics, $3^{\text {rd }}$ edn. Readind, MA: AddisonWesley Publishing Co, Inc.

[179] A.D. McGillivray (1968) "Nernst-Planck equations and the electroneutrality and Donnan equilibrium assumptions", $J$. Chem. Phys., vol.48, pp. 2903-2907.

[180] J.C. Ellory and V.L. Lew (1974) "A $\mathrm{K}^{+}$-dependent phosphatase in the membranes of low- $\mathrm{K}^{+}$-type erythrocytes", Biochim.Biophys. Acta., vol. 332, pp.215-220.

[181] O.S. Hajjawi and R.C. Hider (1987) "Malonate transport in human red blood cells", Mol.Cellular Biochem, vol. 75, pp. 43-49.

[182] J. Brahm (1983) "Urea permeability of human red cells", J.Gen.Physiol. vol.82, pp.1-23.

[183] R.J. Naftalin and G.D. Holman (1977) Transport of Sugars in Human Red Cells, in Membrane Transport in Red Cells, Ellory, J.C. and Lew, V.L (eds.), pp. 257-300. London: Academic Press Inc (London) Ltd.

[184] T.J. Wheeler (1986) "Kinetics of glucose transport in human erythrocytes: zero-transport efflux and infinite-trans efflux at $0^{\circ} \mathrm{C}^{\prime}$, Biomembranes, vol.862 (2), pp.387-398.

[185] J.D. Young and J.C. Ellory (1977) Red Cell Amino Acid Transport, in Membrane Transport in Red Cells, Ellory, J.C. and Lew, V.L. (eds.), pp.301-326. London: Academic Press Inc. (London) Ltd.

[186] G. Tunnicliff (1994) "Amino acid transport by human erythrocyte membranes", Comp. Biochem. Physiol., vol. 108 (4), pp.471-478.

[187] R. Motais (1977) Organic Anion Transport in Red Blood Cells, in Membrane Transport in Red cells, Ellory, J.C. and Lew, V.L. (eds), pp.197-220. London: Academic Press Inc (London) Ltd.

[188] A.G. Lowe and A.R. Walmsley (1987) "A single halfturnover of the glucose carrier of human erythrocyte", Biochim. Biophys. Acta, vol.903 (3), pp.547-550.

[189] O.S. Hajjawiand R.C. Hider (2009) "Asymmetry of the malonate transport system in human red blood cells", European J.Sci. Res, vol.31 (4), pp.534-545.

[190] C.Toyoshima and T. Mizutani (2004) "Crystal structure of the calcium pump with a bound ATP analogue", Nature, vol. 430 , pp. 529-535.

[191] N. Price and L.Stevens (1999) Fundamentals of Enzymology. Oxford: Oxford University Press.

[192] L. Lacko, B. Wittke and P. Geck (1975) "Interaction of steroids with transport system of glucose in human erythrocyte", J.Cellular Physiol., vol.86 (2), pp.673-680.
[193] P.G. LeFevre (1961) "Sugar transport in the red blood cell: structure-activity relationships in substrates and antagonists", Pharmacol. Rev., vol.13, pp.39-70.

[194] S.L.Cranmer, A.R.Conant, W.E.Gutteridge and A.P.Halestra (1995) "Characterization of the enhanced transport of L- and D-lactate into human red blood cells infected with Plasmodium falciparum suggests the presence of novel saturable lactate protein", J.Biol. Chem., vol. 270, pp. $15045-15052$

[195] S. M. Goldin, (1982) Reconstitution as an Assay and as a Physical Tool for Purification of Erythrocyte Membrane Transport Proteins, in Red Cell Membranes- A Methodological Approach, Ellory, J.C. and Young, J.D. (eds.), pp.301-320. London: Academic Press Inc (London) Ltd.

[196] G.F. King and P.W. Kuchel (1984) “ A proton n.m.r. study of iminodipeptide transport and hydrolysis in the human erythrocyte. Possible physiological roles for the coupled system", Biochem. J., vol.220, pp.553-560.

[197] W.L.Moss, (1910) "Studies on isoagglutinins and isohemolysins", Bull John Hopkins Hosp., vol.21, pp.63-70.

[198] J.R. Sachs (1972) "Recoupling the Na-K pump", J.Clin. Invest., vol.51 (12), pp.3244-3247.

[199] J.W. Gibbs (1873) "A method of geometrical representation of the thermodynamic properties of substances by means of surfaces", Transactions of the Connecticut Academy of Arts and Sciences, vol.2, pp.382-404.

[200] D.J. Hanahan, J. Ekholm and G. Hildenbrandt (1973) "Biochemical variability of human erythrocyte membrane preparations, as demonstrated by sodium-potassiummagnesium and calcium adenosine triphosphatase activities", Biochemistry, vol.12 (7), pp.1374-1387.

[201] M. Höfer (1981) Transport Across Biological Membranes. Boston, MA: Pitman Advanced Publishing Program.

[202] V.T Marchesi and G.E. Palade (1967) "The localization of Mg-Na-K-activated adenosine triphosphatase on red cell ghost membranes", J.Cell Biol., vol.35, pp.385-404.

[203] S. Dissing and J.F.Hoffman (1990) "Anion-coupled $\mathrm{Na}$ efflux mediated by the human red blood cell $\mathrm{Na} / \mathrm{K}$ pump", J.Gen.Physiol., vol. 96 (1), pp.167-193.

[204] V. L. Lew and H.G. Ferreira (1977) The Effect of Ca on the $K$ Permeability of Red Cells, in Membrane Transport in Red Cells, Ellory, J.C. and Lew, V.L. (eds), pp.93-100. London: Academic Press Inc (London) Ltd.

[205] P.J. Hilton, W. McKinnon, E.C. Gravett, J. M.R. Peron, C.M Frampton, M.G. Nicholls and A.Gwyn (2010) "Selective inhibition of the cellular sodium pump by emicymarin and 143 anhydroxy bufadienolides", Steroids, vol. 75 (13-14), pp. 1137-1145. 